\title{
Transformation of Global Supply Chains in the Manufacturing Industry as a Result of the Coronavirus Pandemic*
}

\author{
Róbert Hausmann
}

This essay seeks to find out how the coronavirus pandemic may change the international organisation of economic value creation and promote its ongoing transformation. Today's production and service activities are built on international outsourcing and low stocks. Global production organisation has extended supply chains, with different production functions being performed on different continents, and supply chains have also become strongly exposed to Chinese imports. Industries where safety stocks last shorter are hit harder by the economic crisis that has emerged on the back of the pandemic. This poses serious challenges to business models built on the just-in-time system and the lean approach. In response to the current problems, global supply chains may become shorter and more regional during the economic recovery, and they may use multi-sourcing and increase safety stocks. Digitalisation and automation may accelerate, since supply chains will need more data, faster decisions and feedback to ensure a more flexible safety stock policy and more automated production and warehousing. Automation also transforms jobs, making it crucial to develop the skills of workers and to retrain them.

Journal of Economic Literature (JEL) codes: M21, O33, F60

Keywords: global supply chains, digitalisation, robotisation and automation, business economics, coronavirus pandemic

\section{Introduction - In which framework can 21st century production organisation be interpreted?}

Products and services are not created in distinct companies but rather according to the principles of the international division of labour and efficiency, complemented by safety and business continuity considerations. The examination of value-adding activities is based on the theory of comparative advantages by Adam Smith and the

\footnotetext{
* The papers in this issue contain the views of the authors which are not necessarily the same as the official views of the Magyar Nemzeti Bank.
}

Róbert Hausmann is an Analyst at the Magyar Nemzeti Bank.Email: hausmannr@mnb.hu

The Hungarian manuscript was received on 4 June 2020.

DOI: http://doi.org/10.33893/FER.19.3.130153 
division of labour built on that, due to which the different phases of the production process are separated and performed by different actors and firms. The decision on exactly which company should perform a particular production phase depends on several factors (geographical location, business profile, company size, technological preparedness), but ultimately this production organisation issue is decided based on business efficiency. Nowadays, the efficiency of international corporations and supply chains cannot be interpreted within state borders, and it has become inseparable from international trade. 'The flow of goods and services creates the link between the different locations in the division of labour: raw materials flow to parts manufacturers, then from there intermediate goods flow to the producers of final goods, then final goods flow to consumers through wholesalers and retailers' (Ilyés 2016:51). However, similar to the lower levels of Maslow's hierarchy of individual needs, in particular safety and physiological needs, the division of labour and corporate efficiency can be only enforceable if physical and human capital can flow freely, business continuity is ensured, and international trade is not hindered by one-sided or mutual obstacles. Fulfilment of these conditions is increasingly uncertain due to the coronavirus pandemic; therefore, a focused analysis is warranted regarding long-term and current developments influencing the operation of supply chains and the resulting potential ways and phenomena for supply chains. Nevertheless, due to its topic and for reasons of brevity, this article does not seek to provide an in-depth analysis of the various approaches to value chains and supply chains, the latest research results on supply chain management and trends in the discipline of production management.

Global supply chains are one of the models for business operations, in which the different stages and phases of value-adding activity are performed by different firms in different countries. "Supply chains should not be confused with value chains. Supply chains are interconnected networks of companies providing specific activities, in which the activities of each of the actors involved serve the needs of the final consumer. In other words, the supply chain is an ... interconnected series of corporate value chains..." (Juhász-Dóra 2016:24). The concept of value chains is attributable to Michael E. Porter (1985), who attempted to pinpoint the source of competitive advantages by highlighting the value added of corporate activities, regardless of the organisational background of the division of labour. The term value chain refers to organising the processes necessary for creating a product or a service, such as research and development, design, production, marketing, distribution and support to the final consumer, into a chain (Gereffi - FernandezStark 2011). In Porter's approach, these value-adding activities can be divided into 'primary activities' (production, logistics, marketing, sales and services related to sales) and 'support activities' (infrastructure, human resource management, technological development, procurement) (Porter 1991). The term 'global' suggests that today a major part of value-adding activities is based on the international division of labour and the utilisation of comparative advantages, however Gereffi 
- Fernandez-Stark (2011) note the role of regionalisation and local solutions in establishing the suppliers of the value chain. In global production organisation, activities are not coordinated automatically. Hernández - Pendersen (2017) present the options for governance and organising tasks within value chains. In the case of manufactured goods, 50 per cent of international trade and approximately 70 per cent of the cross-border trade in services comprise intermediate goods and services, which means trade within global supply chains (Ilyés 2016).

Supply chain management deals with the strategic decisions made to ensure the operation of supply chains; it endeavours to improve the competitiveness of the ties among the participating organisations. Supply chain management may be assisted by various tools. These tools can be divided into two categories: the management of real economy processes and the management of risks. Real economy processes are sought to be managed by decisions regarding outsourcing, keeping corporate activities within the firm or insourcing. The same purpose is served by the decisions on ad hoc or strategic partnerships (few or many suppliers, the presence or absence of the coordination of information and plans, which also depends on geographical features), adjustment to fluctuations in demand (demand management) and the use of a complex order fulfilment process. Companies can choose from two types of supply chains for their optimal operation: the lean ${ }^{1}$ supply chain ensuring the steady flow of goods, or the flexible (agile) supply chain guaranteeing rapid response to shifts in demand. Risk management involves intracompany and intercompany internal disruptions, supplier risk and longer transit times, as well as the consequences of political instability and the consequences of unexpected natural or health disasters (Gelei 2010).

Another approach is production management, which examines value creation from the perspective of firms or at the micro level, in contrast to the aggregate, macro-level framework (value chain, supply chain). According to the definition by Chase et al. (1995), production and service operations management deals with the design, operation and improvement of the production system that creates and delivers the firm's primary products or services. Production management is an interdisciplinary field between management and engineering, and as such, it is one of the most typical basic fields of technical management. The scientific basis of production management is provided by operations research, which is based on mathematical foundations. This discipline, focuses on the characteristics of the 'just-in-time' production and the pull mechanism that serves to control the flow of materials in this production system, which is a central feature of the operation of global supply chains (Koltai 2006). Although the just-in-time system reduces the costs of inventories to a minimum, it increases business continuity risks (Gelei 2010).

${ }^{1}$ As in 'streamlined' 


\section{What are the main features of global production organisation and supply chains?}

As one of the main consequences of globalisation, which intensified from the 1980s, companies transformed their business models in line with the principles of the just-in-time system and lean management. ${ }^{2}$ The just-in-time system is an inventory management and production organisation model that serves the current needs necessary for production, thereby reducing the unnecessary costs related to inventory investments. In connection with the just-in-time production organisation, one can mention the lean corporate management and governance concept, which aims to remove from the production process the steps that do not create value for (corporate or household) consumers. The volume of inventories and warehousing dropped due to the introduction of this approach; however, production was complemented with a new aspect, namely outsourcing. The principle of outsourcing states that firms should perform all activities necessary for production by ensuring the lowest possible costs (Figure 1). Onshore outsourcing is when a part of the production process is delegated to a domestic company, and offshore outsourcing refers to a situation where a phase of the value-adding activity is assigned to a foreign company within the supply chain. The reduction in the costs of international transportation and foreign trade (duties and other costs) entailed businesses in distant countries being integrated into production. As a result, every third German industrial company has a major Chinese customer, and 81 per cent of German firms have a Chinese supplier in one form or another. Only four per cent have no ties to China at all (Klöpfel Consulting 2020).

\section{Figure 1 \\ Current business management model of globalisation in the manufacturing industry}

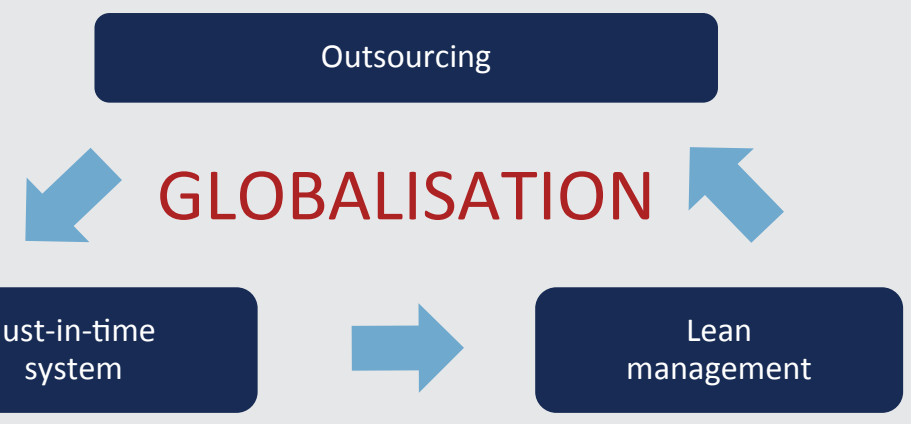

${ }^{2}$ Lean management is a method of corporate governance that improves the efficiency of the production process, while also shortening it, by identifying and minimising losses. It focuses on satisfying customer needs as efficiently as possible. 
The fact that value creation is becoming more cost-effective due to global production organisation benefits both consumers and shareholders; however, this strong interdependence may turn into a detrimental dependence in crisis situations, even in strategic industries. The international division of labour that emerged during globalisation led to a mutual dependence between states, in other words interdependent business and trade relations. Under specific circumstances, this model - which is based on comparative advantages and the level of economic development - is favourable from the perspective of the expansion in the volume of trade, economic development and international cooperation. It makes production cheaper, creates jobs in developing countries and strengthens multilateral ties between countries. However, the operation of global supply chains is exposed to several risks: natural disasters, terrorism, armed conflicts, state regulation, an absence of innovation, the macroeconomic environment and shifting consumer needs. Furthermore, the operation of global supply chains also has to live up to the endogenous financial and production organisation challenges within the chain (Lessard 2013). During a crisis, long supply chains crossing multiple continents can be disrupted, and some final goods and services may be impossible to produce or provide as a result of the application of the production organisation principles described above. If this occurs in strategic industries (e.g. the health industry), it could jeopardise the basic needs of a country, the performance of public tasks and ultimately the self-sufficiency of the country.

\section{Which changes in the global production organisation that have already started may intensify in the future?}

Changes in the business mindset induced by the coronavirus pandemic may lead to the shortening of the long global supply chains that have emerged in the past decades and the spread of import-substituting solutions. The German National Industrial Strategy published in 2019 and the new EU industrial strategy presented in March 2020 both include import substitution, the need to replace foreign supplier capacities, reduce corporate concentration and prevent foreign acquisitions, especially when it comes to strategic industries. One of the conclusions of the German National Industrial Strategy is that German companies operating in key industries should be protected against any hostile takeover attempts from outside the EU. To this end, nationalisation is recommended if all other options have been exhausted in the most important industries, in a partial and temporary manner. Key industries include the automotive, steel and aluminium industries, the chemical and pharmaceutical industries, mechanical engineering, the optical industry and manufacturing of medical devices, the green economy, the defence industry, the aerospace industry and additive manufacturing technology (BMWI 2019). 
The aims of the new EU strategy include addressing the distorting effects of thirdcountry subsidiaries on the EU's internal single market and the development of legal mechanisms that can be used to restrict the access of - mostly state-owned - companies from third countries to the public procurement and funding of the European Union (European Commission 2020). This strategy and the views described in it are reflected in the statement by Margrethe Vestager, the EU Commissioner for Competition, that she has no objection to EU countries appearing on the market and acquiring stakes in a company, provided that this prevents a foreign takeover by a company from a third country (Espinoza 2020).

The coronavirus pandemic may also trigger the inclusion of more partners in the undiversified network of suppliers and the reduction of its one-sided dependence. According to Alex Capri, a visiting senior fellow at the National University of Singapore and a former advisor of KPMG, a massive restructuring of supply chains is to be expected in the wake of the coronavirus pandemic. The researcher expects to see developing countries remain important in terms of sales and suppliers, but firms are foreseen to diversify their sourcing (Tan 2020). This phenomenon is referred to as the reconsolidation of purchases, in other words the reduction of purchases from the same partner (Gelei 2010). The economic concepts of tradable and non-tradable categories may have to be revised, because with regard to previously internationally tradable goods and activities the coronavirus pandemic has shown that they can only be traded without limitations if specific conditions are met (scheduled transportation, sufficient stocks, no state restrictions, constant demand). Moreover, among the values of business models, the priorities of low material and labour costs and the international division of labour may be superseded by substitutability within the company, company group or the state border, the maintaining of various transport routes and the increase of inventory reserves.

In recent years, several analyses have argued that global supply chains are expected to shorten and the number of participating companies and countries linked to a supply chain may decrease. The current operation of global supply chains may change as a result of the so-called equalisation effect, i.e. the process whereby the return on equity declines in developing and moderately developed countries as their wage costs increase. Similar implications can be expected based on the paradox of specialisation, or the rejection of the thesis that one of the cornerstones and key efficiency-boosting features of global production is the division of value-adding activities into smallest possible units and organising them into specialised units. The paradox of specialisation not only concerns production organisation but also leads to a shift in the need for training human capital, among other things. Instead of educational and training programmes focusing on individual industries or business 
functions (e.g. assembly), complex competence-based educational programmes developing problem-solving skills are increasingly in demand. After completing them, people enter the labour market with knowledge that can be applied well in practice and an ability to solve complex challenges, adapt and acquire new skills (Ilyés 2016). Pankaj Ghemawat, a business economics professor at New York University, claims that the shortening of global supply chains is attributable to the equalisation effect as well as chains' fragility. According to Ghemawat, when the SARS virus ravaged Asia in the early 2000s, there were disruptions in several supply chains. As a result, the supply chains consisting of 30-40 phases have substantially shortened. Furthermore, Ghemawat believes that larger stocks are needed due to outsourcing to foreign countries, which could be significantly reduced by domestic or regional production (in contrast to the policy of manufacturing products in different continents and keeping low inventories). ${ }^{3}$

The factors contributing to the simplification and shortening of global supply chains have become more numerous since 2008, and their effects are accelerated by the coronavirus pandemic. Global multi-stage production processes emerged while taking into account the low barriers to trade and the increasing risk of economic interdependences. Global supply chains often include four or five levels, from the original equipment manufacturer (OEM) to Tier 1, Tier 2, Tier 3 etc. suppliers. There are often no or only very loose and indirect links between the OEM at the head of the chain and the Tier 4 or 5 suppliers. According to Peter Guarraia, a partner at Bain\&Company in Chicago and global supply chain expert, 60 per cent of the managing directors of the largest companies involved in global supply chains are not aware of the supply chain processes beyond the Tier 1 suppliers (McGee Edgecliffe-Johnson 2020). Therefore, if disruptions arise in sourcing or production, the OEM is not informed about the difficulties faced by suppliers and end suppliers are also informed about problems that surface at OEMs only with a delay. In global supply chains, developments which encourage rethinking the international division of labour already started proliferating in the 2010s. These included the global financial crisis from 2008, the introduction of Chinese export quotas on rare earth metals in 2010, the volcano eruption in Iceland in the same year, the earthquake and tidal wave in 2011 in Eastern Japan, the flooding in Thailand in 2011 and the trade conflict between the United States and China that has been unfolding since 2018. This process is reinforced now by the disrupted and, in certain cases, disintegrating supply chains due to the coronavirus pandemic (Shih 2020). As a result of the processes described above, 12.9 per cent of the value creation of the world

\footnotetext{
${ }^{3}$ Multinational manufacturers moving back to America. Economist, 12 May 2011. https://www.economist. com/business/2011/05/12/moving-back-to-america. Downloaded: 15 April 2020.
} 
economy occurred in global supply chains in 2017, which was 0.5 percentage points lower than in 2007 (13.4 per cent). However, the values of the different countries vary widely: most Eastern and Central Eastern European countries managed to increase their share within supply chains between 2007 and 2017. For example Hungary's value added produced within global supply chains grew by 4.8 percentage points in this period, rising from 23.0 to 27.8 per cent (Li et al. 2019).

\section{Which sectors and supply chains are affected the most negatively by the coronavirus pandemic and why?}

From a liquidity and profitability perspective, the sectors that are most affected by the negative economic consequences of the pandemic are tourism, air transport and retail trade; those moderately affected include the automotive industry, logistics, the oil and gas industry as well as financial services; the least affected may be the pharmaceutical industry, construction and machinery (Figure 2). The expected sales revenues and profit outlook of tourism and travel services are dampened by the fact that tour operators need to cancel some of the trips planned for the high season. In air travel, a prolonged shutdown causes liquidity problems for the firms, and balance sheet adjustment becomes harder due to aircraft purchases that are based on continuous borrowing and the use of flexible ticket pricing models. With the exception of fast-moving consumer goods, even retail trade may show a marked liquidity shortage and a drop in profits. In the automotive industry, logistics and the oil and gas industry a massive short-term liquidity shortage may arise, but the profitability of these sectors is probably less at risk. In the automotive industry and transportation, firms' exposure to the crisis also depends on company size and their position in the supplier chain. The unit price of oil has lost more than three quarters of its value since the onset of the crisis, which may cause short-term liquidity problems for businesses active in the sector, however, these difficulties may ease as demand gradually picks up. The economic crisis triggered by the coronavirus pandemic may weigh heavily on the profitability of the financial sector, whereas the pharmaceutical industry, construction and machinery (with the exception of the automotive industry) are expected to feel less of the negative effects. The profitability of the financial sector could fall mainly due to low interest rates, monetary policy measures, the introduction of temporary credit moratoriums and the drop in lending activity (Roland Berger 2020). 


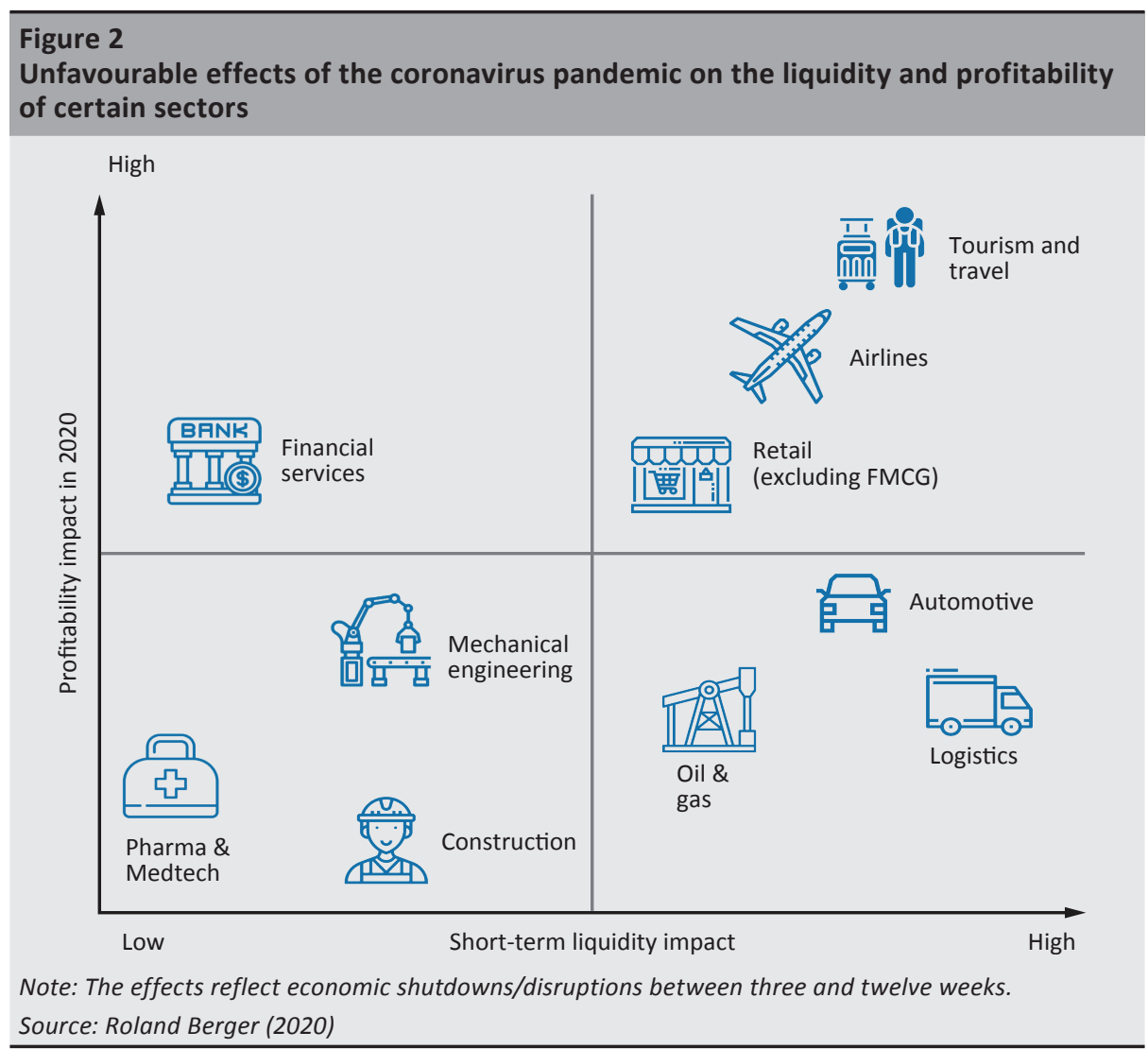

The exposure of industries to the economic crisis triggered by the coronavirus pandemic correlates with their inventory amounts and stockpiling policies. A correlation can be detected between the size of inventories observed in the different industries and the negative effect of the crisis on the given industries. In the industries where inventories last longer and therefore no further imports are needed, the crisis may exert a more moderate impact. Lower inventories, which have typically emerged in the spirit of the just-in-time system, lean management and optimisation, are not sufficient to maintain the same level of production in a period of temporary liquidity shortages and insufficient demand, so the factories in these industries are forced to shut down earlier. Globally, the automotive industry has inventories that last only one to three months, which is one of the lowest in the industrial sector, making it the most vulnerable for example when there is a risk of a pandemic. Commercial firms offering clothing, mass products and consumer 
goods have inventories that last two to five months, which may be enough to weather even a moderately long shutdown. The inventories of companies that mainly produce high-tech products and use semiconductors last for five to eight months, while pharmaceutical corporations can continue production for ten to thirteen months (Figure 3). Inventories lasting for more than six months allow a longer economic shutdown to be overcome. Detailed data on the inventory policies of the different industries are also available (Alicke et al. 2020) (Table 1). ${ }^{4}$

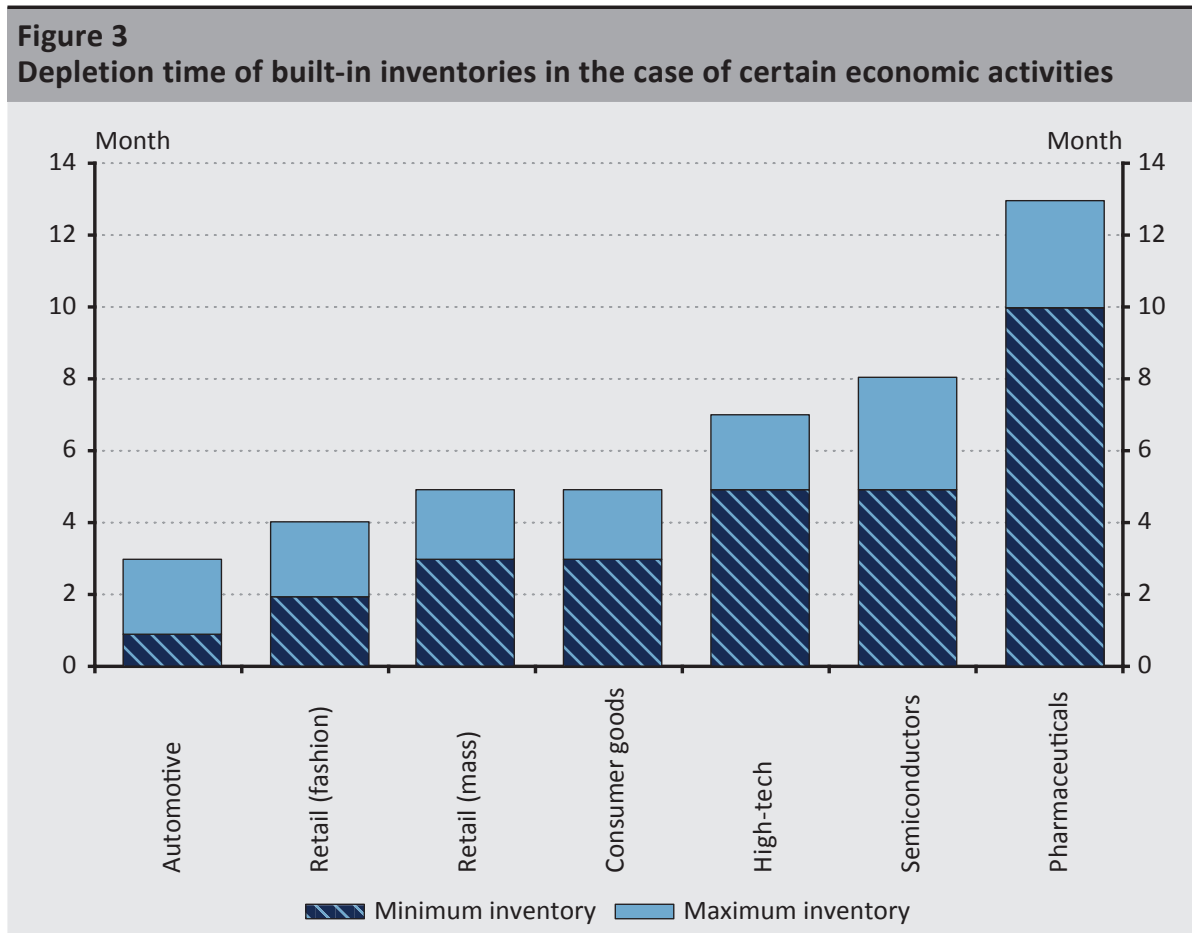

Note: The minimum inventory means the average minimum reserve amount that value chains active in the given field/sector have. The maximum inventory (aggregated with the minimum inventory) means the average maximum reserve amount that value chains active in the given field/sector have.

Source: Compiled based on Alicke et al. (2020)

\footnotetext{
${ }^{4}$ The calculations were performed while examining the disruption or absence of Chinese supplies due to the coronavirus pandemic.
} 


\begin{tabular}{|c|c|c|c|c|c|c|c|}
\hline \multicolumn{8}{|c|}{$\begin{array}{l}\text { Depletion time of built-in inventories by activities within the supply chain in certain } \\
\text { sectors (days) }\end{array}$} \\
\hline & $\begin{array}{l}\text { Automotive } \\
\text { industry }\end{array}$ & $\begin{array}{c}\text { Retail } \\
\text { (fashion) }\end{array}$ & $\begin{array}{l}\text { Retail (mass } \\
\text { product) }\end{array}$ & $\begin{array}{l}\text { Consumer } \\
\text { good }\end{array}$ & High-tech & $\begin{array}{l}\text { Semi- } \\
\text { conductors }\end{array}$ & $\begin{array}{l}\text { Pharmaceutical } \\
\text { industry }\end{array}$ \\
\hline $\begin{array}{l}\text { Tier } 2 \\
\text { supplier }\end{array}$ & $30-40$ & - & - & 20-30 & $40-60$ & - & $35-70$ \\
\hline $\begin{array}{l}\text { Tier } 1 \\
\text { supplier }\end{array}$ & $7-17$ & $15-35$ & $60-90$ & $60-90$ & $55-70$ & $70-110$ & $120-140$ \\
\hline $\begin{array}{l}\text { Assembly/ } \\
\text { Packaging }\end{array}$ & $2-12$ & $15-29$ & 10-17 & 10-17 & $19-45$ & $60-90$ & $55-100$ \\
\hline $\begin{array}{l}\text { Regional } \\
\text { distribution } \\
\text { centre }\end{array}$ & - & $15-23$ & 15-17 & 14 & - & - & $80-90$ \\
\hline $\begin{array}{l}\text { Market } \\
\text { buffer }\end{array}$ & $0-30$ & $21-28$ & 7 & - & $24-40$ & $20-30$ & - \\
\hline Total inventory & 39-99 & $66-115$ & $92-131$ & 104-151 & $138-215$ & $150-230$ & $290-400$ \\
\hline \multicolumn{8}{|c|}{$\begin{array}{l}\text { Note: Empty cells indicate missing data. } \\
\text { Source: Compiled based on Alicke et al. }\end{array}$} \\
\hline
\end{tabular}

\section{What changes in corporate governance and production organisation are expected as a result of the coronavirus pandemic?}

Due to the negative impacts of the coronavirus pandemic on supply chains, many companies are expected to transform their business models after the crisis. Key aspects of the anticipated transformation may be as follows:

a) Regionalisation of production, shortening supply chains: The supplier base necessary for production will be localised in the OEM's country and its economic region. Along the model based on the lean approach, the localisation strategy that has been coming into focus in Japan since the 1970s may become preferred. The production system of Toyota operates based on this principle. Its headquarters are in Japan, and its suppliers are mainly based in neighbouring countries rather than on other continents. Toyota's subsidiary in the United States also operates with a similar approach. Out of their suppliers related to their plant in Georgetown, Kentucky, 350 are located in the United States, and 100 of them are within the state of Kentucky (Shih 2020). If German industrial firms applied a similar approach in their production on account of the economic crisis triggered by the coronavirus pandemic, Hungary may be prioritised over other production sites that are located farther away. Germany's openness towards the regionalisation or localisation of supply chains is reflected in the statement by Peter Altmaier, the federal minister for economic affairs and energy, from the spring of 2020, according to which it is wise to reduce one-sided dependence 
in certain areas to reclaim national sovereignty. Besides the regionalisation of production, Altmaier also emphasised the importance of common European projects, primarily in pharmaceuticals production. ${ }^{5}$ The foundations and ideological basis for the localisation and regionalisation of production and the shortening of supply chains can already be found in Small Is Beautiful: Economics as if People Mattered by Schumacher (1973). ${ }^{6}$ The shortening of supply chains would not only increase security of supply but also promote local job creation, increase tax revenues, and it may reduce emissions and the ecological footprint of production due to falling transport volumes (Jackson - Morrow 2020).

b) Multi-sourcing and accumulating safety stocks: Involving numerous suppliers in the supply chain that produce the same product and strategic stockpiling may ensure business continuity in a crisis. Although the diversification of suppliers and obtaining the same product from several firms operating in different countries as well as safety and strategic stockpiling entails additional costs, based on the lessons learnt from the current crisis, these measures may reinforce business continuity and reduce the vulnerability of global supply chains. Of course, there are industries where this is not feasible due to geographical or other factors, such as the production processes focusing on the use of rare earth metals. However, in the pharmaceutical industry, the Danish Novo Nordisk, which produces 50 per cent of the world's insulin stock, already has inventories for five years in preparation for a shutdown (Shih 2020). The practices of the Danish corporation may serve as an example when transforming the business strategies of other sectors and companies.

c) Economies of scale and changing the product mix: The principle of 'one factory, one product' may be replaced by 'one factory, multiple products'. The global organisational principle of automotive manufacturing is that one production plant manufactures one model. For example, the BMW $X$ series is manufactured exclusively in Spartanburg, South Carolina, and 70 per cent of the cars produced there are exported. Geographical concentration in production is widespread not only in the automotive industry, it has also caught on globally in the case of electronic devices and fast-moving consumer goods in recent decades, because this solution has maximised production efficiency. If one factory produced more than one product at the same time, it would facilitate the regionalisation of production organisation and could ensure the uninterrupted functioning of supply chains in the event of an emergency (Shih 2020).

\footnotetext{
${ }^{5}$ Germany would like to localize supply chains, nationalization possible, minister says. Reuters, 13 March 2020. https://www.reuters.com/article/us-health-coronavirus-germany-pharmaceut/germany-would-liketo-localize-supply-chains-nationalization-possible-minister-says-idUSKBN2101BH. Downloaded: 8 April 2020.

${ }^{6}$ In Hungarian: A kicsi szép (Tanulmányok egy emberközpontú közgazdaságtanról)
} 
d) Establishment of centres coordinating the operation of supply chains: OEMs should manage the internal processes of the supply chains and the decisions pertaining to the overall supply chain together with the other firms in the chain. This can be achieved in several ways (Faria et al. 2020; Alicke et al. 2020). At the level of supply chains, working groups should be established where the main participants in the supplier chain are represented, and they should also be temporarily expandable with the representatives of employer and employee stakeholder groups and financing parties, in particular lending banks, as well as experts, if necessary. The working group can utilise big data (a large dataset based on actual data) to obtain real-time information in a crisis about the production, employment and financial position of the companies within the supply chain, and it can also explore the consumer environment and the external conditions, which allows it to intervene in a more rapid and targeted manner to maintain uninterrupted production, if necessary. These centres coordinating operation should not hamper the independence of the firms in the supply chain or the exercising of ownership rights, and they may not interfere with decisions of companies not pertaining to the operation of the supply chain. When the crisis is over, the centres and working groups coordinating the operation of supply chains should not be abolished, as they can continue to ensure the flow of information within the supply chain, the assessment of the continuously incoming data and the overall coordination of the processes related to production. This may take the form of a so-called supply chain control tower, the main aim of which is to ensure and maintain transparency within the supply chain and address the arising risks (Deloitte 2019; Trzuskawska-Grzesińska 2017).

e) Digitalisation and automation in activities of supply chains: The automation of the less complex activities of production lines and the enhancement of the business model with digital solutions may improve corporate efficiency and productivity. The coronavirus pandemic may encourage producers to replace the easily automatable production processes that require the on-site presence of workers with robots. This could affect those countries more where firms perform lower value-added activities within global supply chains. According to the analysis by Hawksworth et al. (2018), automation may unfold globally in three overlapping waves rather than in a linear way: the algorithm wave (focusing on simple processes) is already under way, the augmentation wave (pertaining to repeatable processes) may be completed in 2020, and the autonomy wave (focused on complex workflows requiring substantial human capital) may culminate in the 2030s. In Hungary's Visegrád peers (dark columns in Figure 4), the share of jobs affected by the three waves of automation is 40 per cent, which is high by international standards. This is because the proportion of low value-added manufacturing activities is higher in these countries than in Western European states. The process of automation is accelerated by economic crises, 
because low-skilled workers become costly for many businesses as corporate revenues are dented, and it is often worth replacing them with robots, or these firms increase their productivity by using higher qualified workforce (Jaimovich 2012; Muro et al. 2020). Moreover, the detrimental effects of the pandemic may encourage producers to increasingly incorporate digital solutions in their business models. These include cloud-based solutions, the $5 \mathrm{G}$ mobile internet and the Internet of Things (IOT), production organisation based on big data solutions, artificial intelligence, the deployment of $E R P^{7}$ and $C R M^{8}$ software supporting the course of business and the widespread application of e-commerce solutions and cybersecurity software.

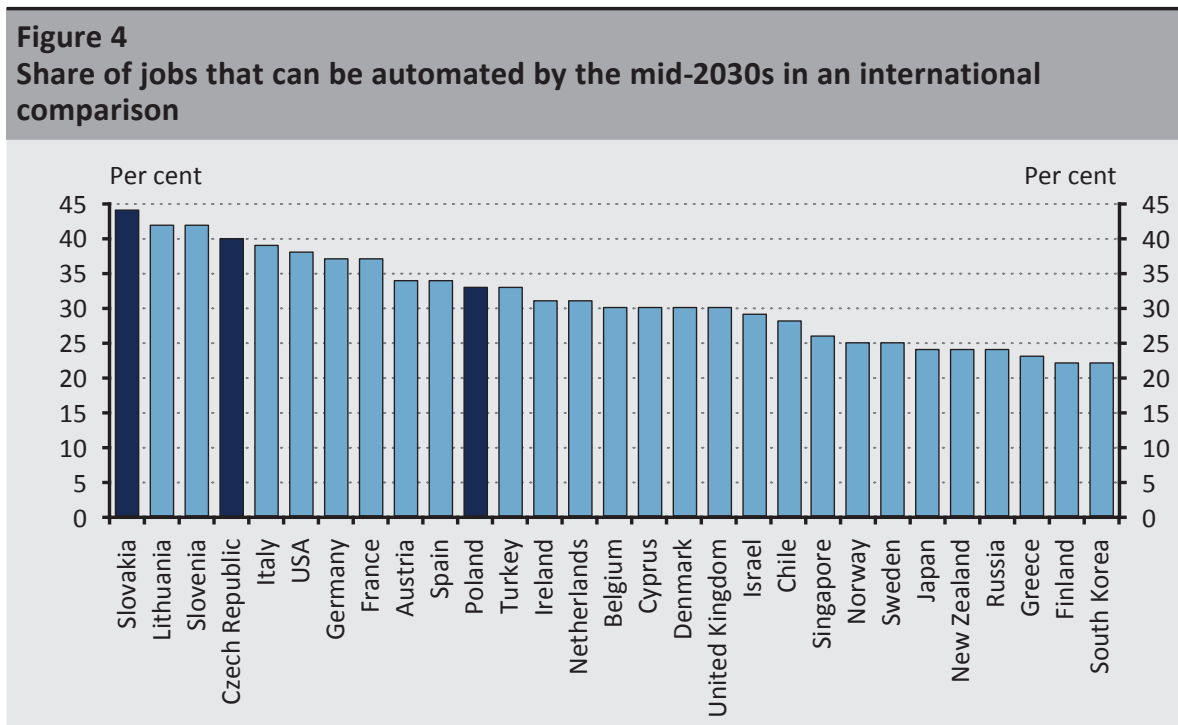

Source: PWC - OECD PIAAC data collection (Hawksworth et al. 2018)

The current condition of global supply chains and the change in their maturity are difficult to measure, because trade statistics do not take into account the features of production organisation and the firms or the trade in goods and services within corporate groups. The trade in value-added statistics (OECD TiVA) improve the measurability of supply chains' value-creating capacity, although they hardly quantify the activities at the beginning and end of the production process, even though their value added is among the largest (Ahmad 2019). The logic behind the trade in value statistics is used by the UNCTAD-EORA GVC Database (Casella et al. 2019) and the World Trade Organization's GVC Participation Index ${ }^{9}$ (WTO 2018).

\footnotetext{
${ }^{7}$ Enterprise Resource Planning

${ }^{8}$ Customer Relationship Management

${ }^{9}$ Trade in Value-Added and Global Value Chains
} 
The latter creates a profile of the countries under review based on the value-added content of exports, the share of exports produced within global value chains, the proportion of services within exports and the share of the trade in intermediate goods. On the other hand, the Supply Chain Index - which assesses the maturity of global supply chains and is prepared by Supply Chain Insights - differs from the databases based on trade in value-added statistics, as it centres on corporate profitability indicators, examining corporate groups rather than countries and ranking supply chains according to three factors. The first is balance, based on the relationship between the annual growth of the supply chain and the return on the capital invested. The second factor is strength, which assesses the margin within the supply chain and inventory turnover. The third is resilience, which is based on the robustness of the relationship between the two factors examined by the strength aspect, the margin and inventory turnover. Based on the change in the three factors between 2010 and 2016, supply chains in the automotive industry, the chemical industry, the food industry, other retail trade, the pharmaceutical industry and telecommunications are ranked. According to the results, 40 per cent of the ten most successful supply chains in the automotive industry are European, 40 per cent are Asian and 20 per cent have American ties. In the ten most successful chemical industry supply chains, there is only one European one among the Asian and American peers, and it is placed 10th. There are no European ones among the most successfully developing food industry supply chains, and there are only two Europeans among the distributors of other retail products. There are merely three European chains among the pharmaceutical industry supply chains exhibiting the most successful growth, and there is no supply chain from the old continent among those active in telecommunications (Cecere-Breskovna 2018).

In the 2010s, most of the dynamically developing supply chains that became longer and more complex were related to East Asia and the United States; therefore, as a result of the coronavirus pandemic, the supply chains operating in these regions should make their operating models more modern and efficient. Since in the 2010s the supply chains related to East Asian and North American OEMs developed the most (see the results of the Supply Chain Index in the previous paragraph), their length, complexity and the number of companies participating in them have increased considerably. The negative economic effects of the coronavirus pandemic principally impact long and complex supply chains that comprise many companies: therefore, East Asian and North American supply chains should also revise and possibly shorten their operating models. However, this shift is easier in East Asian countries, because the companies in the supply chain are more concentrated geographically than their peers in North America. East Asian countries have the capacity and the corporate network to perform both higher and lower value-added activities, whereas North American supply chains are structured in a way that they perform high value-added activities efficiently in the country of the OEM, while 
they outsource the lower value-added activities in the supply chain to another continent or region (for example to East Asia) (Gelei 2010:430). Accordingly, North American countries need to consider transforming their supply chains and making lower value-added activities more competitive to successfully regionalise their production activities. Although in Europe relatively fewer supply chains became longer and more complex in the 2010s, this is attributable to the shortcomings of the European corporate model in innovation and competitiveness; therefore, it is time for European supply chains to be made more innovative and digitalised and their creativity and research and development capacities to be boosted.

\section{Features of digital supply chains - the Supply Chain $\mathbf{4 . 0}$ model or the supply chains of future}

In supply chains operating on the basis of Industry 4.0 which use the solutions of automation and digitalisation, decision-making is faster and rests on more detailed information, thereby facilitating adjustment to different situations. Besides shortening supply chains, the most crucial impact of the coronavirus pandemic on the operation of supply chains may be the all-encompassing digitalisation. The change in activities within supply chains may be accelerated by the availability, compilation, structuring and forecasting (and nowcasting) of data related to current production activities and future economic activities, expected demand and external conditions (macroeconomic developments, weather). For average products, forecasting should be performed weekly, while in the case of fast-moving consumer goods it should be done daily to ensure the efficient functioning of supply chains. This is the main channel of big data analyses in corporate activities. More detailed information is necessary because the personalisation of corporate products and services is increasingly important, as consumers are looking for products and services that increasingly match their individual needs. This requires microsegmentation and mass personalisation in business planning. In addition, the efficiency of supply chains' operation may also be improved by integrating artificial intelligence solutions into business processes, which may facilitate the automatic correction of supply chains' potential operational shortcomings and errors. Furthermore, robots play an increasingly central role in digital and automated supply chains, as they can increase the number of completed products in a unit of time in loading, manufacturing and logistics (Alicke et al. 2016). In the supply chains that are transformed as described, the nature of information flows also changes. Formerly linear information flows are replaced by bidirectional and multidirectional data flows between the activities that constitute the supply chain. This is also referred to as Supply Chain 4.0 (Ferrantino - Koten 2019). 
The coronavirus pandemic accelerates digitalisation processes in the economy, because its business implications necessitate a more flexible safety stock policy as well as more automated production and warehousing. Digital supply chains are supply chains where the value-creating activities as interpreted by Porter are performed using 21st century infocommunication technologies. Automatic supply and inventory management allows for the continuous adjustment of the amount of the safety stock within a supply chain, depending on internal and external circumstances. To ensure the automation of warehousing and logistics, the use of programmable robots and transport equipment and the deployment of sensors and radio frequency identification (RFID) systems becomes crucial (Alicke et al. 2016). Since the operation of these technologies requires fast and reliable internet access with a low lag and massive data traffic enabling communication between the equipment, the related infrastructure must be developed before they appear on a large scale. This calls for further enhancing $5 G$ technology, opening up new $5 \mathrm{G}$ frequencies, network development and the widespread application of small cell systems. To reduce the demand for human labour in production, the acquisition of humanoid robots (exoskeleton) and huge amounts of 3D printers are required, generating substantial investment demand. However, in connection with substituting human capital with technological solutions, studies have shown that robotisation will not replace human labour-based production but rather supplement it (Ferrantino - Koten 2019).

Estimates show that automation within supply chains would affect approximately one-fifth of the employed persons in the Hungarian economy, and therefore their retraining and further training are of key importance. Besides making the course of business more efficient and improving corporate productivity, automation also fundamentally transforms the labour market. According to a study prepared by the Institute for Economic and Enterprise Research of the Hungarian Chamber of Commerce and Industry, the jobs of 165,000 employed persons could be replaced completely with robots and automation solutions, and there are another 567,000 employed persons who could be partially replaced ( 4 and 15 per cent of total employed persons, according to the data of the National Tax and Customs Authority of Hungary), as they perform mostly automatable subtasks. The largest share of Hungarian employed persons, 28 per cent, work in a profession where automation can play a supplementary role, while 27 per cent of employees work in positions that can hardly be automated or not at all (Nábelek - Vági 2019). The most automatable positions include those in office and administrative fields, agriculture and forestry, industry and construction, as well as those of machine 
operators, assemblers, drivers and unskilled workers (Figure 5). ${ }^{10}$ Since the coronavirus pandemic is expected to strengthen automation, the opportunity for retraining and further training should be offered generally and in particular in the employment groups listed above, by providing financial state subsidies. Over the medium term, increasing the proportion of tertiary graduates may prove to be a solution for maintaining employment levels.

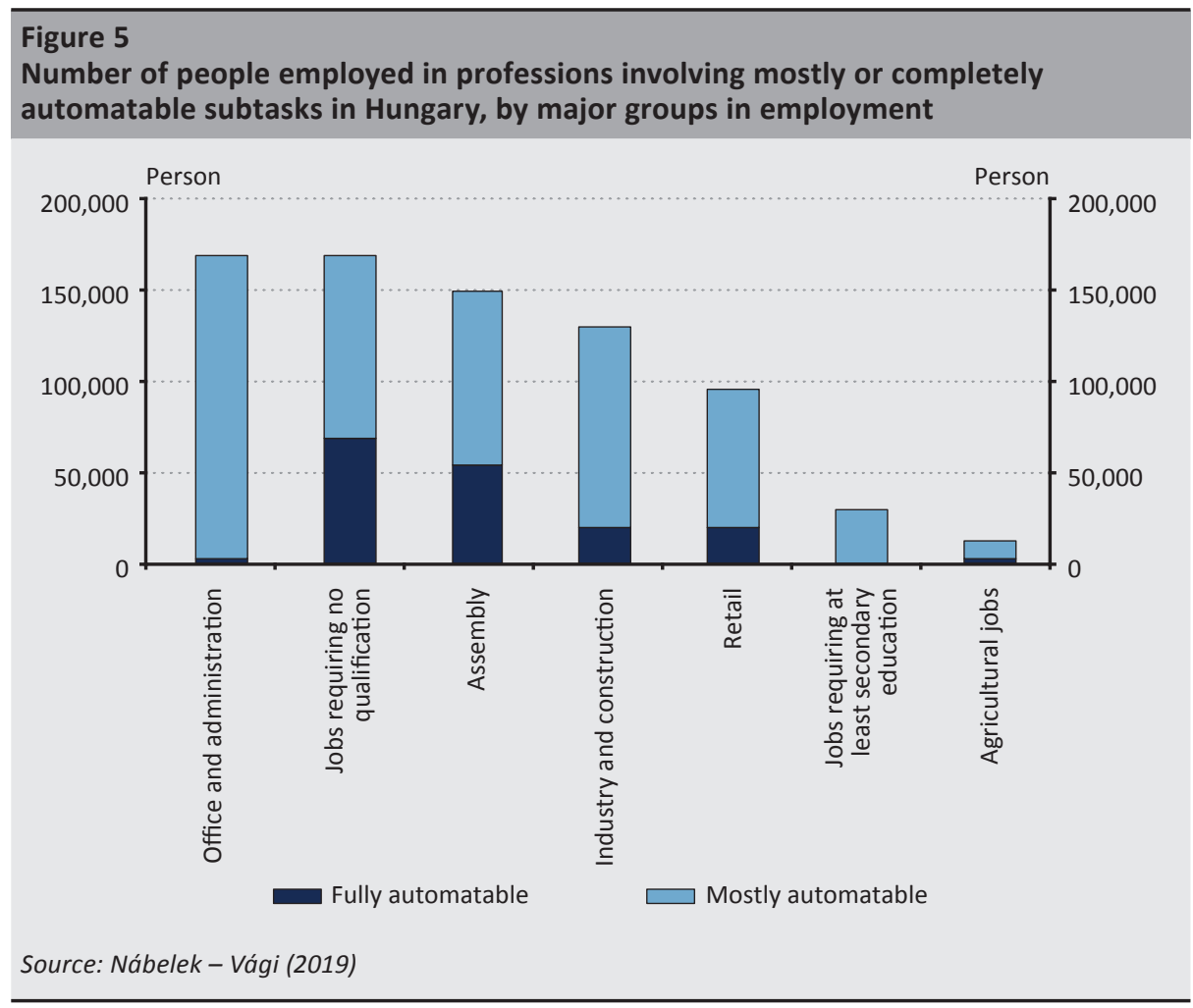

${ }^{10}$ A similar conclusion was drawn by a study prepared by Fine et al. (2018) at McKinsey on the automation opportunities of Hungarian jobs. According to their analysis, 24 per cent of the current jobs in Hungary can be potentially automated by 2030 , if an average scenario is realised. Based on this, automation could affect the jobs of approximately one million employed persons. 


\section{Summary - trends and incentives in the transformation of global supply chains}

This descriptive analysis presented the effect of the coronavirus pandemic on international production organisation as well as the related long-term transformation processes of the operation of global supply chains. While there is no optimal and universal method for economic value creation, the essay concludes that five trends can be identified that significantly influence the operation of global supply chains, partly as a result of the continuously developing production management, and partly as an effect of the pandemic. The first trend is the regionalisation of international value creation and the simultaneous shortening of supply chains. This is followed by multi-sourcing and accumulating safety stocks, as well as the shift from production focusing on a single product towards manufacturing several products. Another trend is the establishment and development of centres coordinating the operation of supply chains, as well as boosting digitalisation and automation within firms and in intercompany relations. The findings on the regionalisation of supply chains and the geographical dimension of their operation are related to Hernández and Pendersen (2017). Moreover, the analysis expands the field of supply chain management with practical and empirical insights and conclusions (Gelei 2010), with a special focus on risk management. The examination is based on the trends and experiences from previous years on the one hand and, and on the forecasts of advisory firms on the other hand, as there are no actual data for the corporate developments for the entire present year. When the actual data become known, it may be worth returning to the assessment of the changes in supply chains.

Progress in these five trends, the reduction of the adverse effects in the operation of global supply chains that arose on the back of the pandemic and companies' upgrading of supply chains may be facilitated by several economic policy decisions. These include state subsidies for strategic industries (e.g. the health industry) and the sectors which suffered the biggest losses in the coronavirus pandemic. Additionally, over the long run, the state may also promote the relocation of corporate activities to Hungary that could potentially return to Europe from distant continents by establishing a business environment that is favourable from a taxation and administrative perspective and that rests on e-governance solutions. Economic policy may stimulate the digitalisation of supply chains and the spread of Industry 4.0 solutions from three directions. First, the continuous development of digital infrastructures (state support for developing $5 \mathrm{G}$ technology), the facilitation of their corporate integration (state funds for the establishment of infocommunication technologies and mentoring programmes presenting their 
application) as well as the enhancement of digital skills of employed persons (teaching competence-based digital skills that support problem-solving and increasing the share of tertiary graduates).

\section{References}

Ahmad, N. (2019): Improving the accounting frameworks for analyses of global value chains. In: Dollar, D. - Ganne, E. - Stolzenburg, V. - Wang, Z. (eds.): Global value chain development report 2019. Technological innovation, supply chain trade and workers in a globalized world. World Trade Organisation - IDE-Jetro - OECD - UIBE - World Bank Group. pp. 155-177. https://doi.org/10.30875/37edc817-en

Alicke, K. - Rachor, J. - Seyfert, A. (2016): Supply chain 4.0 - the next generation digital supply chain. McKinsey, October 27. https://www.mckinsey.com/business-functions/operations/ our-insights/supply-chain-40--the-next-generation-digital-supply-chain. Downloaded: 15 April 2020.

Alicke, K. - Azcue, X. - Barriball, E. (2020): Supply chain recovery in coronavirus times plan for now and the future. McKinsey, March 18. https://www.mckinsey.com/businessfunctions/operations/our-insights/supply-chain-recovery-in-coronavirus-times-plan-fornow-and-the-future\#. Downloaded: 8 April 2020.

BMWI (2019): Industrial strategy 2030. Made in Germany. Federal Ministry for Economic Affairs and Energy (BMWi). https://www.bmwi.de/Redaktion/EN/Publikationen/Industry/ industrial-strategy-2030.html. Downloaded: 8 April 2020.

Casella, B. - Bolwijn, R. - Moran, D. - Kanemoto, K. (2019): Improving the analysis of global value chains: the UNCTAD-Eora Database. Transnational Corporations, 26(3): 115-142. https://doi.org/10.18356/3aad0f6a-en

Cecere, L. - Breskovna, A. (2018): The Supply Chain Index - 2018. The Supply Chain Insights. http://supplychaininsights.com/portfolio/the-supply-chain-index-2018/. Downloaded: 16 April 2020.

Chase, R.B. - Aquilano, N.J. - Jacobs, R.F. (1995): Production and Operations Management: Manufacturing and Services. Irwin.

Deloitte (2019): The Supply Chain Control Tower. Fixing age-old issues with modern tools and techniques. https://www2.deloitte.com/content/dam/Deloitte/us/Documents/energyresources/us-supply-chain-control-tower.pdf. Downloaded: 22 April 2020. 
Espinoza, J. (2020): Vestager urges stakebuilding to block Chinese takeovers. Financial Times, 12 April. https://www.ft.com/content/e14f24c7-e47a-4c22-8cf3-f629da62b0a7. Downloaded: 22 April 2020.

European Commission (2020): Making Europe's businesses future-ready: A New Industrial Strategy for a globally competitive, green and digital Europe. Press release, European Commission, 10 March. https://ec.europa.eu/commission/presscorner/detail/ en/ip_20_416. Downloaded: 8 April 2020.

Faria, A.P. - Carneiro, A. - Teixeira, A. - Batista, C. - Sá, C. - Szhao, E. - Alexandre, F. - Anjos, F. - Veiga, F. - Vasconcelos, H. - Pais, J. - Cerejeira, J. - da Silva, J.C. - Tavares, J. - AguiarConraria, L. - Faria-e-Castro, M. - Portela, M. - Straume, O. - Afonso, Ó. - Bação, P. Brinca, P. - Gil, P.M. - Barros, P.P. - Sousa, R. - Esteves, R.B. - Maximiniano, S. - Cruz, S. - Peralta, S. - Sequeira, T. (2020): The Covid-19 crisis calls for pre-emptive monitoring of production and distribution chains. VoxEU, 24 March. https://voxeu.org/article/covid19-crisis-calls-pre-emptive-monitoring-production-and-distribution-chains. Downloaded: 8 April 2020.

Ferrantino, M.J. - Koten, E.E. (2019): Understanding Supply Chain 4.0 and its potential impact on global value chains. In: Dollar, D. - Ganne, E. - Stolzenburg, V. - Wang, Z. (eds.): Global value chain development report 2019. Technological innovation, supply chain trade and workers in a globalized world. World Trade Organisation - IDE-Jetro - OECD - UIBE - World Bank Group, pp. 103-119. https://doi.org/10.30875/10529e69-en

Fine, D. - Havas, A. - Hieronimus, S. - Jánoskuti, L. - Kadocsa, A. - Puskás, P. (2018): Transforming our jobs: automation in Hungary. McKinsey\&Company, May. https://www. mckinsey.com/featured-insights/europe/transforming-our-jobs-automation-in-hungary. Downloaded: 27 April 2020.

Gelei, A. (2010): Az ellátási lánc menedzsmentje (Supply chain management). In: Czakó, E. - Reszegi, L. (eds.): Nemzetközi vállalatgazdaságtan (International Business Economics). pp. 413-441. Alinea Kiadó, Budapest.

Gereffi, G. - Fernandez-Stark, K. (2011): Global Value Chain Analysis: A Primer (2nd edition). Duke Center on Globalization, Governance and Competitiveness, July. https://www. researchgate.net/publication/305719326_Global_Value_Chain_Analysis_A_Primer_2nd_ Edition. Downloaded: 15 April 2020.

Hawksworth, J. - Berriman, R. - Goel, S. (2018): Will robots really steal our jobs? An international analysis of the potential long term impact of automation. PricewaterhouseCoopers. https://www.pwc.com/hu/hu/kiadvanyok/assets/pdf/impact_ of_automation_on_jobs.pdf. Downloaded: 15 April 2020. 
Hernández, V. - Pendersen, T. (2017): Global value chain configuration: A review and research agenda. Business Research Quarterly, 20(2): 137-150. https://doi.org/10.1016/j. brq.2016.11.001

Ilyés, M. (2016): A globális értékláncok szerepe; a globális keretektől a gazdaságpolitikai ajánlásokig (The role of global value chains; from global frameworks to economic policy recommendations). In: Czakó, E. (ed.): A globális értékláncok - elméleti alapok és számbavételi lehetőségek (Global Value Chains - Theoretical foundations and trials for measurement). Working paper No 163, Budapesti Corvinus Egyetem Vállalatgazdaságtan Intézet (Corvinus University of Budapest - Institute of Business Economics), September. http://unipub.lib.uni-corvinus.hu/2613/1/Nkzi_163.pdf. Downloaded: 15 April 2020.

Jackson, B. - Morrow, D. (2020): Coronavirus and the Localization of Supply Chains. Sustainalytics, 9 April 2020. https://www.sustainalytics.com/esg-blog/coronavirus-andthe-localisation-of-supply-chains/\#_edn2. Downloaded: 22 April 2020

Jaimovich, N. (2012): Job polarization and jobless recoveries. NBER Working Paper Series No. 18334. (The study was revised in November 2018.) https://doi.org/10.3386/w18334

Juhász-Dóra, K. (2016): Érték-konfigurálás a versenyelönyért: értékláncok, érték-mühelyek és érték-hálózatok (Value configuration for competitive advantage: value chains, value workrooms and value networks). In: Czakó, E. (ed.): A globális értékláncok - elméleti alapok és számbavételi lehetőségek (Global Value Chains - Theoretical foundations and trials for measurement). Working paper No 163, Budapesti Corvinus Egyetem Vállalatgazdaságtan Intézet (Corvinus University of Budapest - Institute of Business Economics), September. http://unipub.lib.uni-corvinus.hu/2613/1/Nkzi_163.pdf. Downloaded: 15 April 2020.

Klöpfel Consulting (2020): Deutsche Manager: Jeder Fünfte hat Angst vor Produktionsstillständen. https://www.kloepfel-consulting.com/presse/pressemitteilungen/ deutsche-manager-jeder-fuenfte-hat-angst-vor-produktionsstillstaenden-39187/. Downloaded: 8 April 2020.

Koltai, T. (2006): Termelésmenedzsment (Production Management). Budapesti Múszaki és Gazdaságtudományi Egyetem (Budapest University of Technology and Economics). Typotex Kiadó. https://wiki.estiem.bme.hu/_media/targyak/termmen/koltai_tamas-termelesmenedzsment.pdf. Downloaded: 4 August 2020.

Lessard, D. (2013): Uncertainty and risk in global supply chains. In: Elms, D.K. - Low, P. (eds.): Global value chains in a changing world. World Trade Organization - Fung Global Institute - Temasek Foundation Centre for Trade and Negotiations. pp. 195-220. https://www.wto. org/english/res_e/booksp_e/aid4tradeglobalvalue13_e.pdf. Downloaded: 4 May 2020. 
Li, X. - Meng, B. - Wang, Z. (2019): Recent patterns of global production and GVC participation. In: Dollar, D. - Ganne, E. - Stolzenburg, V. - Wang, Z. (eds.): Global value chain development report 2019. Technological innovation, supply chain trade and workers in a globalized world. World Trade Organisation - IDE-Jetro - OECD - UIBE - World Bank Group, pp. 9-43. https://doi.org/10.30875/6aa1a271-en

McGee, P. - Edgecliffe-Johnson, A. (2020): Companies' supply chains vulnerable to coronavirus shocks. Financial Times, 9 March. https://www.ft.com/content/be05b46a5fa9-11ea-b0ab-339c2307bcd4. Downloaded: 22 April 2020.

Muro, M. - Maxim, R. - Whiton, J. (2020): The robots are ready as the COVID-19 recession spreads. Brookings Institution, 24 March. https://www.brookings.edu/blog/ the-avenue/2020/03/24/the-robots-are-ready-as-the-covid-19-recession-spreads/. Downloaded: 15 April 2020.

Nábelek, F. - Vági, E. (2019): A szakmák automatizálhatósága és az automatizáció lehetséges munkaeröpiaci hatásai Magyarországon (The automatability of jobs and the possible effects of automation on the labor market in Hungary). Kutatási Füzetek (Research Papers) 2019/3, MKIK Gazdaság és Vállalkozáskutató Intézet (HCIC Institute for Economic and Enterprise Research). https://gvi.hu/files/researches/587/ipar_4_0_feor_ tanulmany_191128.pdf. Downloaded: 8 April 2020.

Porter, M.E. (1985): Competitive Advantage: Creating and Sustaining Superior Performance. The Free Press, New York.

Porter, M.E. (1991): Towards a dynamic theory of strategy. Journal of Strategic Management, 12(Special Issue, Winter): 95-117. https://doi.org/10.1002/smj.4250121008

Roland Berger (2020): World economic growth plunges due to coronavirus - which industries suffering the most. https://www.rolandberger.com/en/Point-of-View/Coronavirus-Currentstatus-and-economic-impact-forecast.html. Downloaded: 15 April 2020.

Schumacher, E.F. (1973): Small Is Beautiful: Economics as if people mattered. Harper Collins, 2010 (Reprint).

Shih, W. (2020): Is it time to rethink globalized supply chains? MIT Sloan Management Review, 19 March. https://sloanreview.mit.edu/article/is-it-time-to-rethink-globalizedsupply-chains/. Downloaded: 8 April 2020.

Tan, H. (2020): There will be a massive shuffling of global supply chains globally after coronavirus shutdowns. CNBC, 20 March. https://www.cnbc.com/2020/03/20/coronavirusshocks-will-lead-to-massive-global-supply-chain-shuffle.html. Downloaded: 8 April 2020. 
Trzuskawska-Grzesińska, A. (2017): Control towers in supply chain management - past and future. Journal of Economics and Management, 27(1): 114-133. https://doi.org/10.22367/ jem.2017.27.07

WTO (2018): WTO "Trade in Value-Added and Global Value Chains" profiles. Explanatory notes. World Trade Organization. https://www.wto.org/english/res_e/statis_e/miwi_e/ Explanatory_Notes_e.pdf. Downloaded: 22 April 2020. 